\title{
Content-Based Instruction of EFL and Its Effects on Learners' Needs in China
}

\author{
Yi Peng \\ School of Foreign Studies, Yangtze University, Jingzhou, China
}

\section{Email address:}

pengyicet4@126.com

\section{To cite this article:}

Yi Peng. Content-Based Instruction of EFL and Its Effects on Learners' Needs in China. Education Journal. Vol. 6, No. 3, 2017 , pp. 116-119. doi: $10.11648 /$ j.edu.20170603.12

Received: February 18, 2017; Accepted: March 8, 2017; Published: May 2, 2017

\begin{abstract}
CBI is a content-centered EFL teaching approach. It has proven to be appropriate to the needs of specific learners. The CBI programs around the world are successful and meaningful. The learners' needs for EFL in China can be described as a pyramid with four categories: test purpose, professional purpose, communicative purpose and mastering purpose. Applying CBI to college English courses in China can improve the status of language learners' needs for testing towards for professional and communicative purposes.
\end{abstract}

Keywords: CBI, EFL, Learner's Needs

\section{Introduction}

As an approach to foreign language education, content-based instruction (CBI) refers to the integration of language learning as well as content learning. CBI is a totally different method of teaching from traditional foreign language teaching methods in so far as "language proficiency is achieved by shifting the focus of instruction from the learning of language per se to the learning of language through the study of subject matter" [1]. The CBI approach has the potential to enhance students' motivation, to accelerate students' acquisition of language proficiency, to broaden cross-cultural knowledge, and to make the language learning experience more enjoyable and fulfilling. [2] A typical CBI curriculum should be subject-matter based, using authentic language and texts and meeting the needs of particular units of students. In an era of language teaching centering on the concept of developing students' Communicative Competence, CBI is truly suitable for enhancing the development of students' four language skills (listening, speaking, writing and reading) emphasizing the functional use of language in real settings. [3].

There are numerous CBI programs throughout the world. In Canada as early as 1960s, CBI was introduced to second language "immersion" programs for K-12 students as a methodological milestone. Since then, meaningful and noticeable language programs in universities emerged in succession such as business courses in French at Drury College, a scientific-technical program in French at Napier College in Scotland, political studies courses at George Washington University in Russia, a course in anthropology in Japanese at Brown University and many others. [4] The general success of those programs indicates it is possible to implement CBI in a variety of ways reaching a positive outcome as long as the administrative support is adequate and teachers' commitment to CBI philosophy is consistent.

\section{Characteristics of CBI Projects Around World}

Considering all the pros and cons, CBI presents a challenging while rewarding alternative to traditional foreign language approaches. In the long run, CBI is a language teaching method worth the previous commitment to it. From the related projects already implemented, some valuable characteristics of CBI can be noticed.

\subsection{Content (Subject)-Centered}

All the programs related to CBI were organized around the study of content (subject) rather than the study of grammar or language itself. Nevertheless, the choice of content and the way in which it was presented varied widely depending on the aims of each individual program and the needs of particular a 
group of students.

With regard to teaching materials, a viable approach is to replace textbooks with a series of authentic materials taken from a broad variety of sources such as newspapers, magazines, TV shows, radio programs, films, and the like. [5] Meanwhile, it is significant to allow some time developing a library of "authentic materials", planning the scope of topics, preparing activities to absorb them. For example, when choosing internet materials, teachers should consider the needs and interests of students carefully. Additionally, students should have access to electronic devices in order to increase their motivation to learn. [6] Furthermore, genuine classroom activities in which students are actively engaged should be strongly encouraged. [7]

\subsection{Challenge-Based Teaching}

In order for CBI projects to function well and achieve their ultimate teaching goals, instructors should be more than skillful language teachers. They must be knowledgeable of the subject area taught and should be well qualified to deliver the knowledge to their students. [8] Under such circumstances, a team-teaching approach is often essential commonly with one language instructor and one subject instructor in the team. But this approach is not the only solution to face the challenge. [9] Single teacher approach can also be efficient and successful as long as the language instructor is knowledgeable about the related subject or has received proper training in the related subject. Apart from that, Berger (2014) also found that game-based method in EFL classrooms can develop learners' motivation and make the learning process more student-oriented, which demands teachers to have higher activity organizing skills. [10]

\subsection{Appropriate to the Needs of Specific Students}

The subjects, topics, content, materials, and teaching activities should meet the linguistic, cognitive, and communicative needs of the students and should be appropriate to their professional needs and personal interests. [11] Another aspect to be noted is about the course syllabus. Brown (2007), for instance, argued that within the profession of language teaching for specific purposes, language course syllabuses can be more motivating for students when they are closely connected to students' specialty courses. [12]

\section{Meets the Needs of EFL Students}

According to some scholars like Liuoliene, A. and Metiuniene, R. (2006), learners' needs or motivation is an essential "driving force" in learning a foreign language. The more intense the needs, the more autonomous learning the students can have in the acquisition process. [13] After engaging in EFL teaching in College in China for 15 years, I found it significant to take learners' needs into consideration while teaching English as a foreign language. I have tried to categorize the needs of Chinese EFL learners into 4 levels: for a test purpose; for a professional purpose; for communication purposes and mastering purposes.

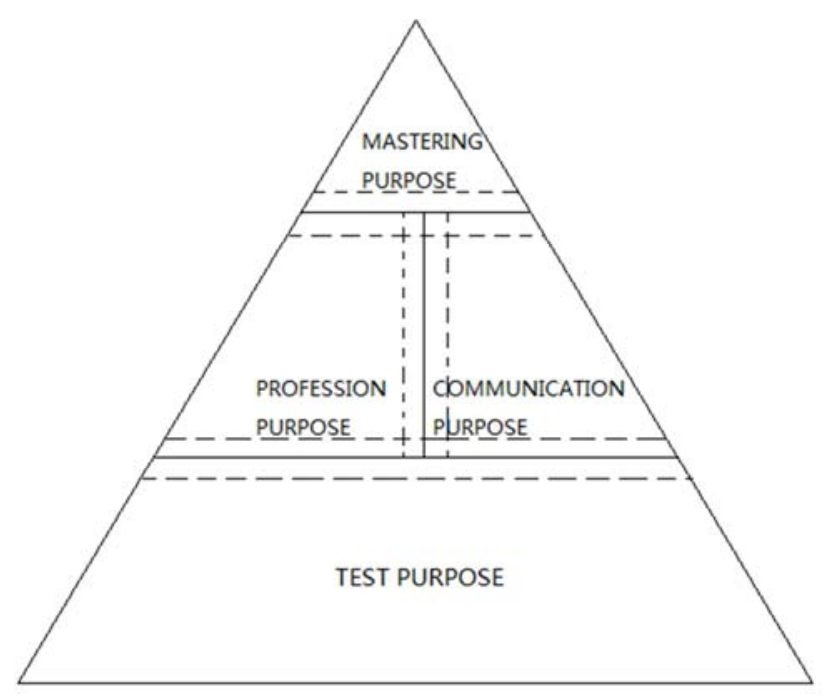

Figure 1. EFL four levels of needs in China.

Form figure 1 we can see that the 4 levels of needs of different EFL learners pile up as a pyramid. Each learner's need can be regarded as a pinpoint inside this pyramid. The learners with different needs learn English for a different purpose with a different relevant point of the pyramid. A considerable number of learners may have multiple purposes as it is shown in the dotted line area. And a learner's need may develop form the bottom toward the top of the pyramid.

Learners for testing purposes constitute the majority of the Chinese EFL learners. This massive group of people begin to learn English from primary school to high school (age 6-18). They learn English just to pass all the examinations they may have during their 12 school years and they might not have a chance to use English to communicate in their life span.

Some of learners for testing purposes eventually enter a university or institute with a major. The needs of this category of learners tend to shift from testing to professional purposes if they want to understand articles in English within their major, use English to communicate with their foreign colleagues or deliver a speech in English in an international conference. At the same time, some learners may have the possibility to visit or study in an English speaking country in the future, to know more about foreign countries, to enjoy original English movies and literature or make foreign friends. This group of learners develop the needs of learning English for communication purposes. The professional and communication purposes may co-exist for learners of an intermediate level (mostly undergraduate students). These two type of needs differ but are closely related to the same important position as shown in figure 1 .

Only an insignificant number of EFL learners ultimately develop the needs for mastering purposes. These learners are seeking the fluency of English as their native language. Mastering purpose always matches those learners who are language teachers, researchers, translators, diplomats and the like. Because of the small quantity of this group of learners, it will not be discussed in this article. 


\section{The Effects of CBI on Chinese EFL Learners}

According to the characteristics of CBI mentioned earlier, the elements of CBI should meet the needs of a specific group of learners. So it is of great necessity to analyze the needs of EFL of undergraduate students in Chinese universities.

As language teachers in higher education, we hope that most of the learners have the required needs to learn English for professional or communication purposes, as it is indicated in figure 2 .

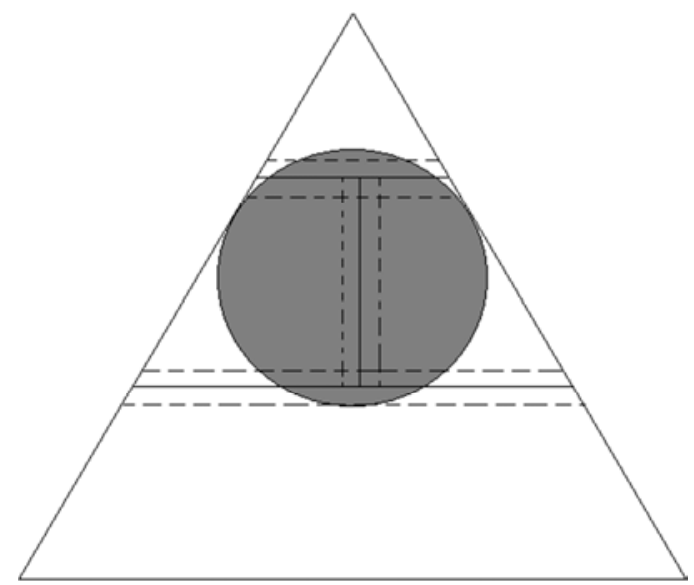

Figure 2. The needs of undergraduate students in Chinese universities: ideal status.

As for the status quo of EFL learners in China, in a survey I conducted among non-English majors, 981 undergraduates in my university took part in it and 468 students (48\%) declared that they learn English in order to pass the examinations required to graduate; only $223(23 \%)$ students claimed they need English to reinforce their profession or academic improvements and $290(30 \%)$ students learn English to expand their horizon and communicate with people from different culture. Therefore, the status quo in Figure 3 presents a different situation from Figure 2.

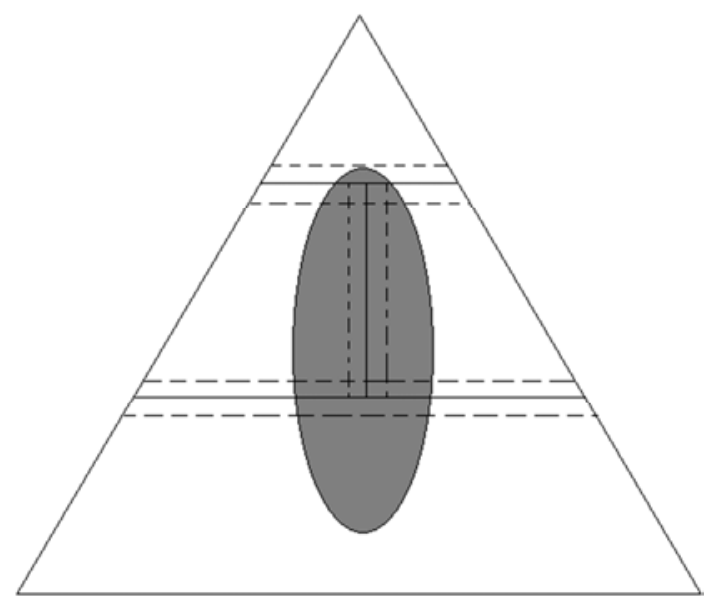

Figure 3. The needs of undergraduate students in Chinese universities: status quo.
A key reason for this result lies in the fact that the content of the college English course instigated no interest in those learners who found the content neither related to their profession development nor practical to enhance their English communicating skills. In summary, to improve the status quo of EFL learners in Chinese colleges, a content- based instruction reforming the college English courses is worth trying.

As language instructors, it is our job to change learners' needs from the status quo in figure 3 towards the ideal status in figure 2. Given the characteristics of CBI mentioned earlier, applying CBI to coaching EFL learners in Chinese colleges are more likely to have positive effects on EFL learners' needs for language learning.

\section{Conclusion}

CBI has several advantages in as much as it is a content-centered language teaching method suited to specific learners' needs increases teaching efficiency, integrates CBI in college English courses to improve students' learning needs. By implementing CBI, students may gain a new interest in English learning for professional or communicating purposes rather than to fulfill a course requirement or pass a course test. Meanwhile, we shouldn't neglect the complexity of setting a thorough CBI college English course system in one particular college with lots of major choices for undergraduates, since for different majors the content of the English course should differ accordingly. To adopt CBI, English teachers in China will also face a challenge that never happened before, because the new content may be a totally different subject to most of them. Positively seeking help from teachers of target subject is a good way to solve this problem. All in all, no matter how difficult it is, as English teachers, it is our job to build a new teaching system with interaction, reflection and creativity to reinforce the development of autonomy or students' needs for language learning, as Bedoya (2014) puts it. [14]

\section{References}

[1] Leaver, Betty Lou and Stephen B. Stryker. 1989. Content-Based Instruction for Foreign Language Classrooms. Foreign language annals 22: 269-274.

[2] Stryker, Stephen B. and Betty Lou Leaver. 1997. Content-Based Instruction in Foreign Language Education: Models and Methods. Washington D. C.: Georgetown University Press. P5.

[3] Stryker, Stephen B. and Betty Lou Leaver. 1997. Content-Based Instruction in Foreign Language Education: Models and Methods. Washington D. C.: Georgetown University Press. P13.

[4] Stryker, Stephen B. and Betty Lou Leaver. 1997. Content-Based Instruction in Foreign Language Education: Models and Methods. Washington D. C.: Georgetown University Press. P19. 
[5] Sternfield, Steven R. 1985. Foreign Language Education and the Psycho-Social Variables of Adult Foreign Language Acquisition. Unpublished doctoral dissertation. University of Southern California.

[6] Ilter, Bnnur G. 2009. Effect of Technology on Motivation in EFL Classrooms. Turkish online journal of distance education 10: 155

[7] Ramirez, Martha I. D. 2014. Developing Learner Autonomy through Project Work in an ESP Class. HOW 21: 66.

[8] Klahn, Norma. 1988. Area-Language Studies: Program on Mexico. New York: School for International and Public Affairs, Columbia University.

[9] Stryker, Stephen B. and Betty Lou Leaver. 1997. Content-Based Instruction in Foreign Language Education: Models and Methods. Washington D. C.: Georgetown University Press. P292.
[10] Berger, J. 2014. Game-based Method to Encourage EFL Learners to Transition to Autonomous Learning. Studies in self-access learning journal 5 (3): 313.

[11] Stryker, Stephen B. and Betty Lou Leaver. 1997. Content-Based Instruction in Foreign Language Education: Models and Methods. Washington D. C.: Georgetown University Press. P302.

[12] Brown, David N. 2007. Language Learner Motivation and the Role of Choice in ESP Listening Engagement. ASp: 159.

[13] Liuoliene, A. and Metiuniene, R. 2006. Second Language Learning Motivation. Santalka, Filologija, Edukologija 14 (2): 97.

[14] Bedoya, Paula A. 2014. The Exercise of Learner Autonomy in a Virtual EFL Course in Colombia. A Colombian jouanl for teachers of English 21 (1): 96. 